\title{
Analysis of the behavior of reinforced concrete columns strengthened with sleeve wedge bolts and a self compacting concrete layer
}

\section{Análise experimental de pilares de concreto armado reforçados por encamisamento com camada de concreto auto adensável}

M. G. MARQUES

mariliagmarques@outlook.com

A. P. A. R. LISERRE

andrea.liserre@gmail.com

R. B. GOMES a

rbggomes@gmail.com

G. N. GUIMARÃES a

gilson.natal@gmail.comr

\begin{abstract}
Strengthening of reinforced concrete columns by jacketing is one of the most common structural rehabilitation techniques in Brazil. For adequate performance, it is necessary, among others, to avoid detachment of the new concrete layer (strengthening material) from the old concrete substrate when the strengthened member is again in service conditions. This paper describes the test results of eight reinforced concrete rectangular columns subjected to combined compression and one-axis bending to evaluate the efficiency of using sleeve wedge bolts across the new concrete/old concrete interface to avoid detachment. The strengthening technique, in this case, consists of adding a layer of self-compacting concrete to one face of the column. Two columns tested were monolithic and named PO (original column) e PR (reference column). The other six columns were strengthened using a new $35 \mathrm{~mm}$ thick self-compacting concrete layer attached to the column face subjected to highest compressive stresses. Column PO had a $120 \mathrm{~mm}$ by $250 \mathrm{~mm}$ rectangular cross section and its results gave information about column behavior without the use of strengthening. Column PR had a 155mm by $250 \mathrm{~mm}$ rectangular cross section and its cross section dimensions matched the strengthened columns but it was cast monolithically. To improve bond conditions between the existing concrete and the new concrete, the concrete surface was roughened and the outermost aggregate was exposed using hydro jetting. Holes along the concrete surface were made to insert the wedge bolts responsible for increasing the bond between the two concrete surfaces. The difference among the six strengthened columns was the position and amount of bolts used. Results indicate that the position and amount of the bolts alters significantly the strength capacity of the columns, since premature rupture by concrete detachment was delayed.
\end{abstract}

Keywords: column, reinforcement, wedge bolts, bending, compression, bond.

\section{Resumo}

Para que um elemento estrutural reforçado por encamisamento tenha um desempenho satisfatório é necessário garantir a transferência de esforços na região da junta do concreto antigo (substrato) com o concreto do reforço. O desplacamento entre o concreto adicionado (material do reforço) e o concreto antigo deve ser evitado quando a peça reabilitada é colocada novamente em serviço. Foram ensaiados oito pilares de concreto armado, submetidos à flexo-compressão reta, reforçados com concreto auto adensável e chumbadores metálicos cruzando a interface de ligação entre os concretos moldados em idades distintas, para evitar o desplacamento entre estes materiais. Dos oito pilares ensaiados, dois eram referências e foram denominados de PO (pilar original) e PR. (pilar referência). Os outros seis foram reforçados acrescentando-se uma camada de concreto auto adensável de $35 \mathrm{~mm}$ à face comprimida. O pilar PO, tinha seção transversal de $120 \times 250 \mathrm{~mm}$, e forneceu informaç̃̃es sobre o comportamento da peça antes da execução do reforço. O pilar PR tinha seção transversal de $155 \times 250 \mathrm{~mm}$, e forneceu informações sobre o comportamento de uma peça monolítica de seção idêntica a dos pilares após o reforço. Para executar o reforço, inicialmente escarificou-se, por hidrojateamento, a zona de interface a ser formada pelo contato entre o concreto do reforço e do substrato. Posteriormente, fizeram-se furos ao longo desta superfície, onde foram inseridos os chumbadores mecânicos responsáveis por aumentar a aderência entre os concretos. A diferença entre os seis pilares reforçados consistia justamente na variação da posição e da quantidade dos chumbadores usados em cada peça. Os resultados obtidos indicaram que a quantidade e a posição destes chumbadores interferiram significativamente na capacidade portante dos pilares reforçados, pois retardavam a ocorrência de uma ruptura prematura por desplacamento entre os concretos do reforço e do substrato.

Palavras-chave: pilar, reforço, chumbadores, deslocamentos e deformações. 


\section{Introduction}

Although the number of studies on the behavior of rehabilitated concrete structures has increased in the last decade, research is needed on the behavior of these structures under service loads. With this in mind, the main objective of this research is to establish strategies, methods and project procedures for rehabilitation of strengthened concrete structures with an emphasis on reinforced concrete columns subjected to one-axis bending and compression. There are several techniques for strengthening reinforced concrete structures and one of the most common in Brazil consists of jacketing a concrete member by adding new concrete, with or without reinforcement, to the sides of the concrete member. This technique is used in columns and fragile mode of failure can result from the detachment of the new concrete added to the column face if the shear stresses resistance at the new concrete - old concrete interface is not adequate. Thus, there is a need to study the bond between these two concretes and to analyze the influence of shear connectors positioned at the interface so that the rehabilitated column acts monolithically.

For the strengthened structural element to have a satisfactory performance it is necessary to guarantee the transfer of internal forces at the new concrete-old concrete interface. This force transfer occurs similarly to force transfer in composite members and it can occur through the concrete itself and through the connectors.

Force transfer through the contact surface of the new and old con- crete is basically done through adhesion, friction and mechanical action of the new substrate with the rehabilitating material. Adhesion of the new and old concrete occurs mainly through mechanical interlock or wedging. Due to capillary absorption, particles of the new concrete are gradually confined in the pores of the old concrete. As the hydration of the cement of the new concrete occurs, there is a physical enlace with the irregularities of the old concrete surface. Force transfer between the contact surfaces by friction appears after breakup of adhesion and this happens after any relative displacement between the strengthening concrete and the substrate. Force transfer through mechanical interlock occurs through a shear key and, in rough surfaces, it is guaranteed by the coarse aggregate across the interface.

When reinforcement across the concrete interface exists, force transfer can occur by dowel action. Dowel action appears when shear forces act at the concrete interface and relative displacement between the two concrete surfaces appear. This displacement will try to shear any bolts present across the concrete interface. The bolt offers shear resistance that is added to the shear resistance of the contact surfaces. When relative displacement between the concrete surfaces exist, separation of the concrete surfaces will generate tension forces in the bolts and these will react by compressing the concrete surface and friction at the concrete interface will increase.

Although the evaluation of the force transfer at the interface between the substrate and the new concrete is essential to the

\section{Figure 1 - Column dimensions}

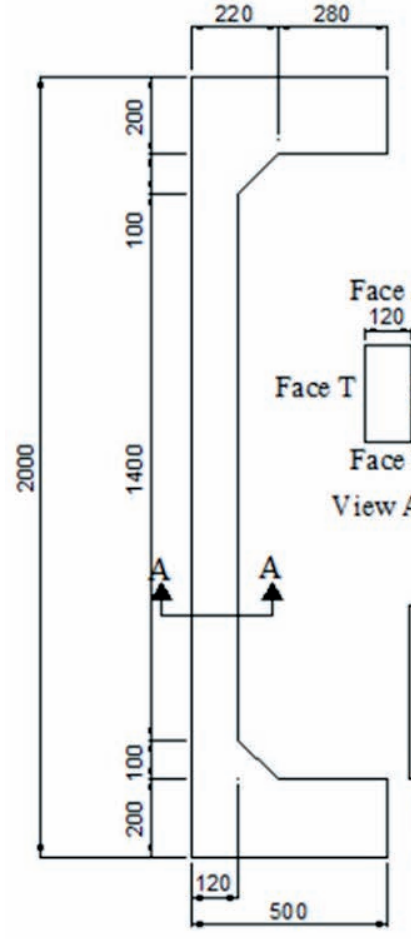

Original column

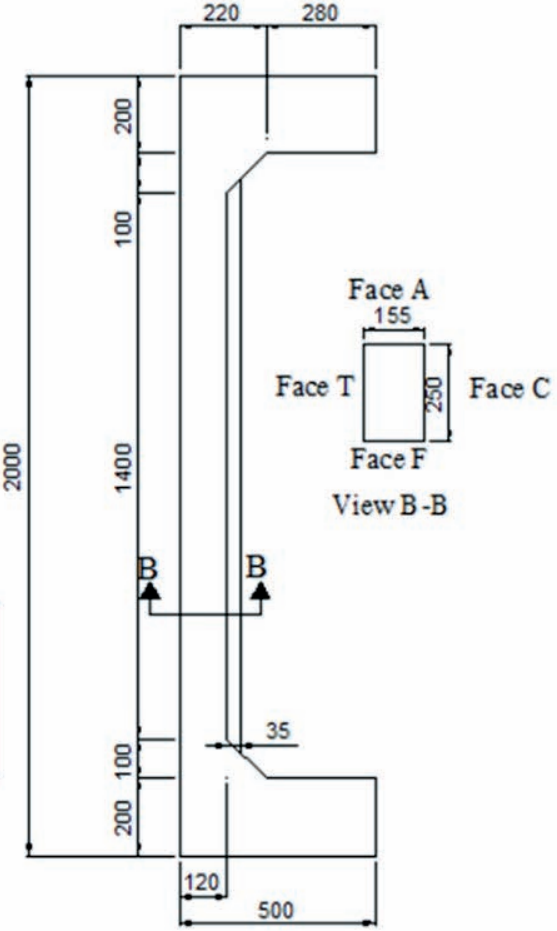

Strenghtened columns 


\section{Figure 2 - Sleeve wedge bolt components}

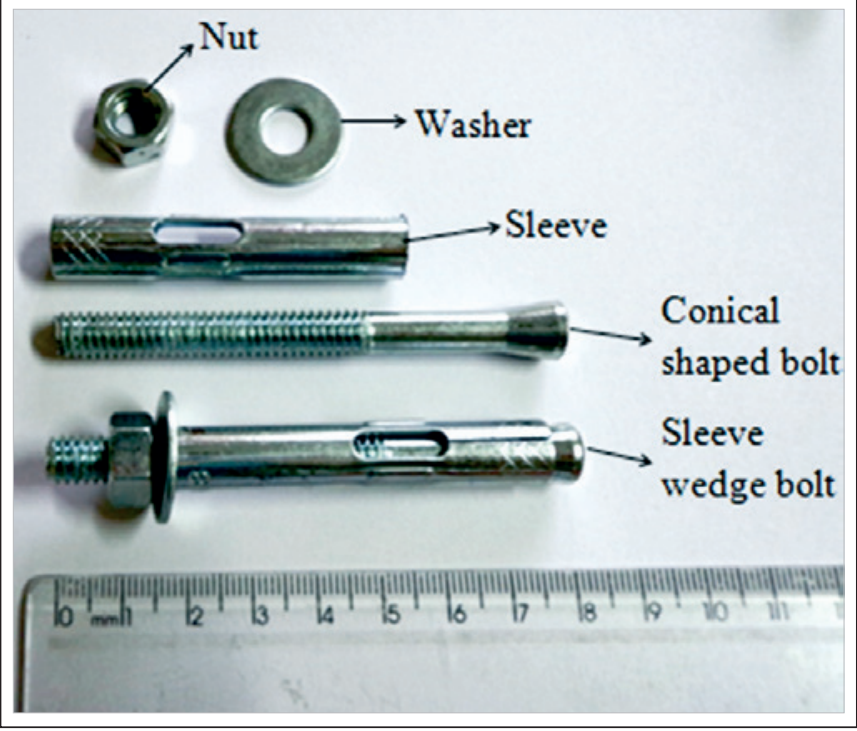

success of the rehabilitating work, there is still no consensus among the researchers on the best way to determine the interface shear stresses. This evaluation is complex and difficult to achieve, because not only physical and chemical phenomena occur at the interface, but the interface can also be subjected to a great variety of stresses due to mechanical actions in the structure itself (SOUZA (1990) [1]). MORENO (2002) [2] adds that the adhesion mechanism between the two cimentitious materials is a complex phenomena due to the heterogeneous nature of the concrete substrate and the strengthening materials.

The mechanical properties of the strengthening material, the concrete substrate surface preparation and the amount of reinforcement or bolts across the interface are some of the factors that influence interface shear resistance.

Recent work has been done at the Master's Program in Civil Engineering at the School of Civil Engineering of the Federal University of Goiás with the intent to evaluate the influence of reinforcement or bolts across the concrete interface to resist shear stresses in columns strengthened by jacketing. The objective of these works is to evaluate the influence of bolt type and quantity placed along the concrete interface of columns strengthened by jacketing when subjected to compression and one-axis bending.

OMAR (2006) [3], SAHB (2008) [4] and NASCIMENTO (2009) [5] studied strengthened columns and experimental evidence showed significant gains in column resistance as the cross section's dimensions are increased by jacketing. However, although the column

Figure 3 - Steel reinforcement details

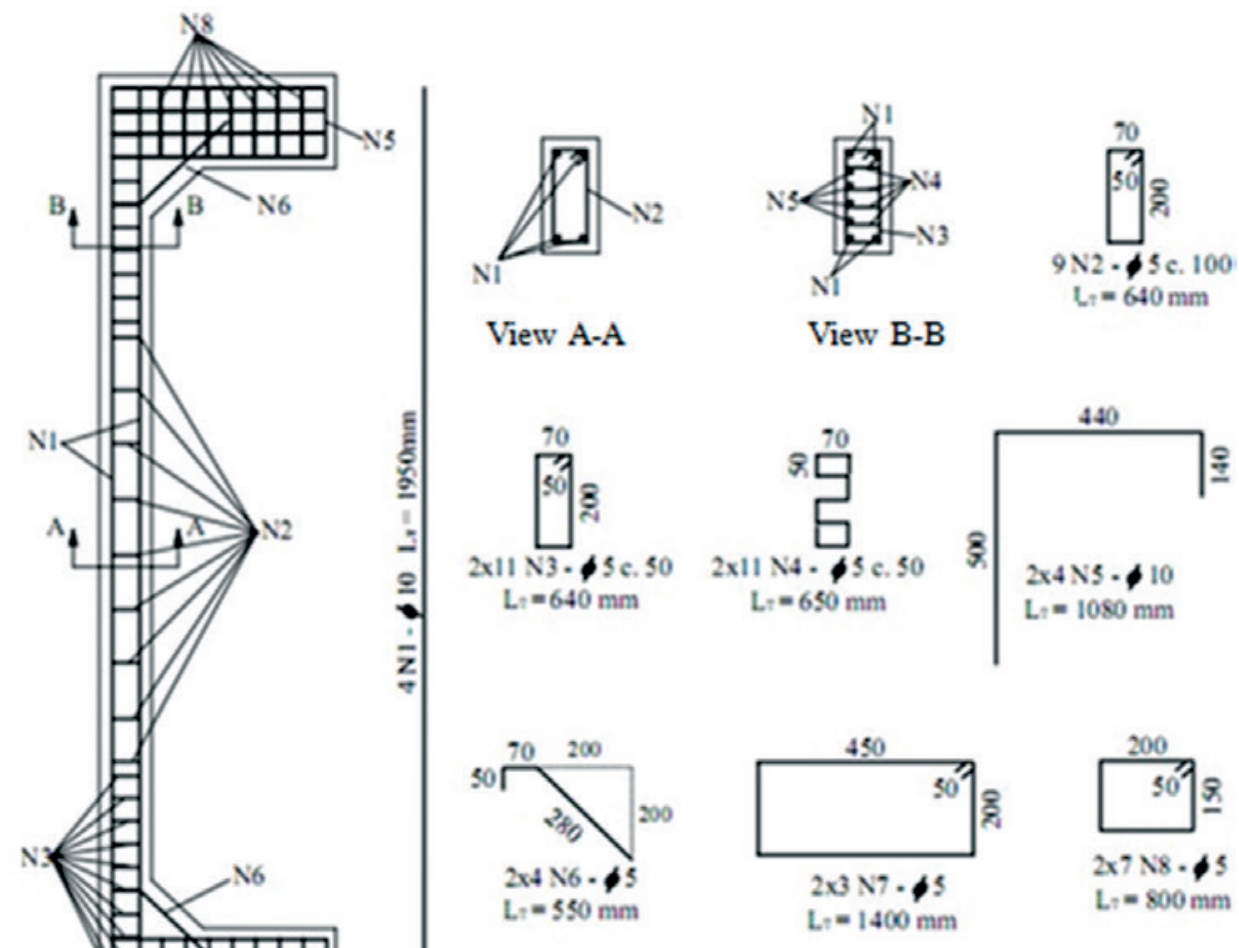

Dimensions: $\mathrm{mm}$ 
capacity increased compared to the original column, fragile and premature rupture was observed in some columns due to detachment of the new strengthening concrete from the old concrete substrate. Hence, new work is under way at the Federal University of Goiás such as those by MARQUES (2014) [6] e FERREIRA (2014) [7].

\section{Experimental program}

This work presents the experimental results of eight rectangular columns subjected to compression and one-axis bending. Six of the eight columns were strengthened at the compression face with the addition of a concrete layer and use of wedge bolts along its length to increase adhesion between the old concrete substrate and the new concrete layer (MARQUES (2013) [6]).

Column nominated as PO corresponds to the original column without strengthening with the rectangular cross section of $120 \mathrm{~mm}$ by $250 \mathrm{~mm}$. Six strengthened columns were originally cast with a $120 \mathrm{~mm}$ by $250 \mathrm{~mm}$ cross section and a $35 \mathrm{~mm}$ concrete layer was later added to the compression face. Therefore, the six strengthened columns had a $155 \mathrm{~mm}$ by $250 \mathrm{~mm}$ cross section when tested and they were nominated as P150-18, P150-26, P75-50, P75-34e, P75-34i e P75-42. All six were strengthened with sleeve wedge bolts placed perpendicular to the concrete interface formed after adding the new concrete $35 \mathrm{~mm}$ layer. Column nominated as PR was cast with a $155 \mathrm{~mm}$ by $250 \mathrm{~mm}$ cross section and has the same cross section as the strengthened columns but was cast monolithically. Since column PR was cast monolithically it should correspond to the strengthened column at its best as far as column load capacity is concerned. Column length was $2000 \mathrm{~mm}$. Self-compacting concrete with a $40 \mathrm{MPa} 28$-day compressive strength was used.

\subsection{Column properties}

Figure 1 shows column cross sectional dimensions. The columns were built such that two corbels, one at the base and another at the top, allowed for the application of a vertical force with an eccentric- ity that will provide bending moment at the column mid-length and the column will be under compression and one-axis bending. After strengthening, the smaller cross section dimension was increased from $120 \mathrm{~mm}$ to $155 \mathrm{~mm}$ due to addition of a $35 \mathrm{~mm}$ concrete layer. Wedge bolts were placed but no additional steel reinforcement was added to the column.

To avoid detachment of the new concrete layer, sleeve wedge bolts with $8 \mathrm{~mm}$ nominal diameter and $80 \mathrm{~mm}$ effective length were used. The wedge bolt comes complete with conical bolt, jacket, washer and nut as shown in Figure 2. This type of bolt was chosen to continue the study initiated by SAHB (2008) [4].

Column longitudinal steel reinforcement consisted of 4 rebars of 10 $\mathrm{mm}$ nominal diameter $\left(A_{\mathrm{s}}=314 \mathrm{~mm}^{2}\right)$. Transverse steel reinforcement consisted of $5 \mathrm{~mm}$ diameter hoops placed every $100 \mathrm{~mm}$ at column mid-length and spaced every $50 \mathrm{~mm}$ near column ends as illustrated in Figure 3. Concrete cover of $25 \mathrm{~mm}$ followed prescriptions in Brazilian Code NBR 6118:2007 Code [8], considering a weak aggressiveness durability class for columns. Prescriptions in EUROCODE 2 (2007) [9] says that minimum rebar cover should assure effective transmission of bond, protection against corrosion and adequate fire resistance.

Table 1 shows the column properties such as cross section dimensions, amount of bolts, bolt vertical spacing, bolt alignment and positioning and initial vertical load eccentricity for each column. Figure 4 shows bolt distribution for each column. Columns were named following a simple rule:

- PO/PR: Original column and Reference column;

- $P X-Y$, where $X$ is the vertical bolt spacing in $\mathrm{mm}$ and $\mathrm{Y}$ is the amount of bolts.

Column production consisted in the preparation of formwork, assembly of reinforcement, concrete casting, curing and formwork removal. Steel formwork was designed to facilitate assembly, removal and reuse. Plastic rebar spacers were used to position the reinforcement in the formwork and guarantee a $25 \mathrm{~mm}$ rebar cover. Approximately 50 days after casting, the jacket was cast. Preparation for casting the strengthened concrete cover included the

\section{Table 1 - Column properties}

\begin{tabular}{|c|c|c|c|c|}
\hline Column & $\begin{array}{c}\text { Cross section } \\
\text { dimensions }(\mathrm{mm})\end{array}$ & $\mathbf{n}$ & $\frac{S_{b}}{(m m)}$ & $\mathrm{n}_{\mathrm{L}}$ \\
\hline $\mathrm{PO}$ & $120 \times 250$ & - & - & - \\
\hline PR & $155 \times 250$ & - & - & - \\
\hline P150-18 & $155 \times 250$ & 18 & 150 & 2 \\
\hline P150-26 & $155 \times 250$ & 26 & 150 & 3 \\
\hline P75-50 & $155 \times 250$ & 50 & 75 & 4 \\
\hline P75-34e* & $155 \times 250$ & 34 & 75 & 2 \\
\hline P75-34i** & $155 \times 250$ & 34 & 75 & 2 \\
\hline P75-42 & $155 \times 250$ & 42 & 75 & 3 \\
\hline \multicolumn{5}{|c|}{$\begin{array}{l}n=\text { amount of bolts; sb = vertical bolt spacing; } \mathrm{nL}=\text { amount of bolt lines; } \\
e_{\text {inic. }}=\text { initial load eccentricity: } 60 \mathrm{~mm} \text { for the original column and } 42,5 \mathrm{~mm} \text { for all others; } \\
\text { * subscript } \mathrm{e}=\text { bolts with two external lines; } \\
\text { ** subscript } \mathrm{i}=\text { bolts with two internal lines. }\end{array}$} \\
\hline
\end{tabular}


Figure 4 - Bolt distribution along the column's compressed side
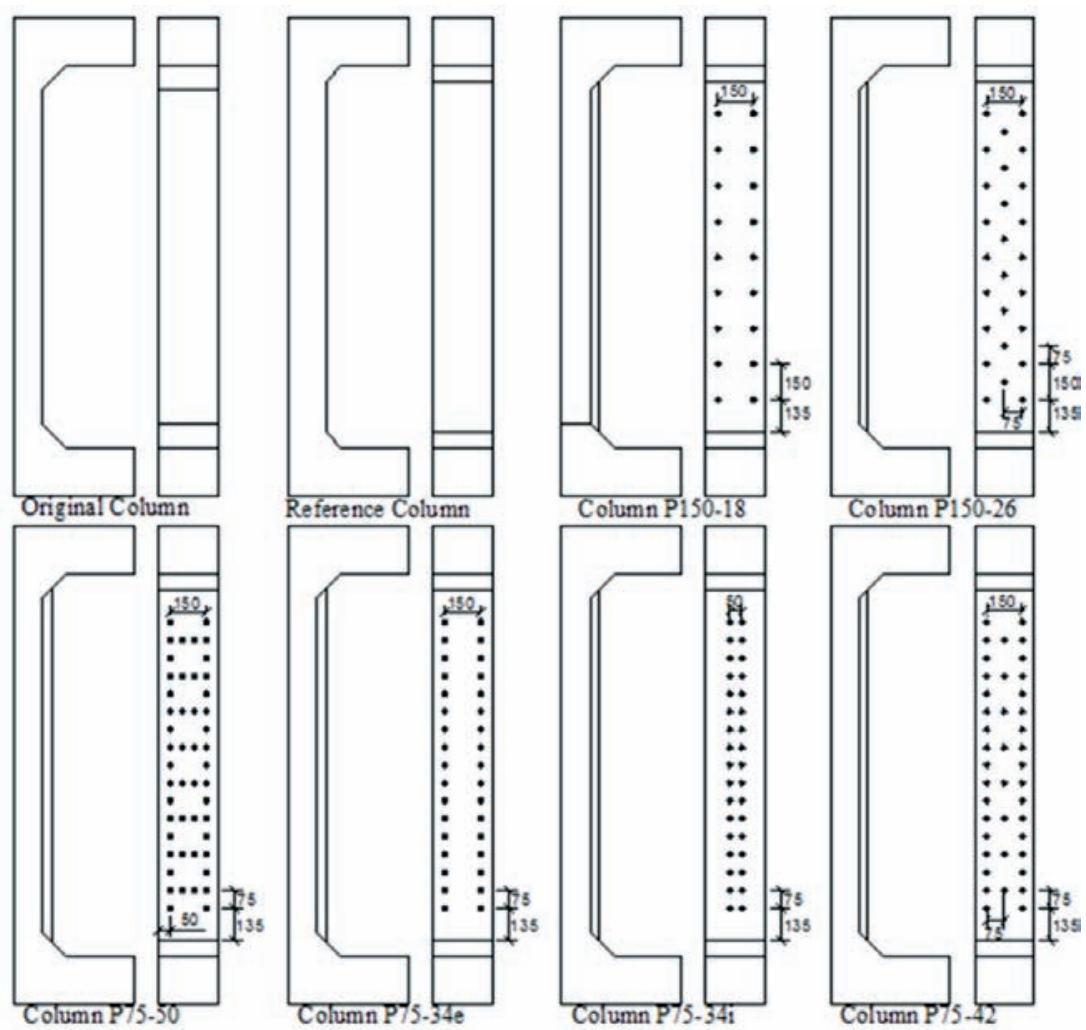

following steps: drilling holes for bolt fixation, hydro jetting the old concrete surface, bolt fixation.

Bolt length was $80 \mathrm{~mm}$. The bolts were placed in holes $65 \mathrm{~mm}$ deep inside the concrete substrate using a large hammer, so 15 $\mathrm{mm}$ of the bolt's length would be positioned inside the new concrete layer. This positioning was used to guarantee a $20 \mathrm{~mm}$ rebar cover as prescribed by Brazilian code NBR 6118:2007 [8], in item 7.4.7.4, that allows a $20 \mathrm{~mm}$ nominal rebar cover for columns under conditions of durability class I aggressiveness. See Figure 5 for bolt placing details. A wrench was used for tightening the bolt's

nut. No other structural adhesive material was used for attaching the bolt to the concrete substrate and the device was fixated purely by mechanical anchorage.

\subsection{Instrumentation}

Steel reinforcement was assembled at the Structural Laboratory of the School of Civil Engineering of the Federal University of Goiás. Steel rebars of the same fabrication lot were used to avoid material properties differences. Longitudinal rebars were numbered 1 to 4 : rebars num-

Figure 5- Bolt positioning details of three different columns

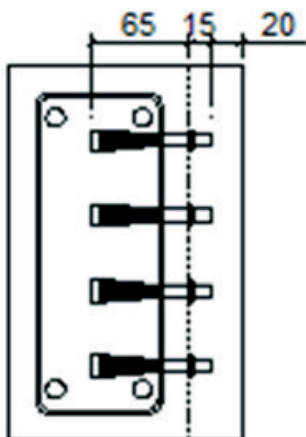

Column P75-42

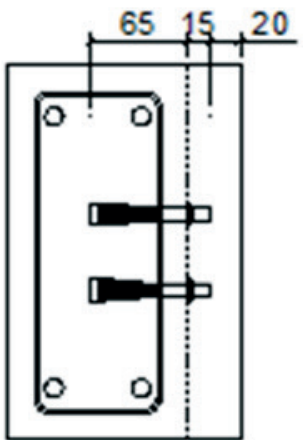

Column P75-34i

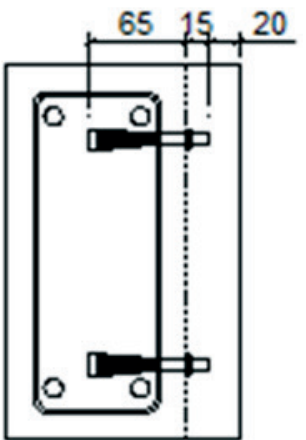

Column P75-34e

Dimensions.mm. 
Figure 6 - Strain gauge positioning

a) reinforcement strains, b) concrete strains

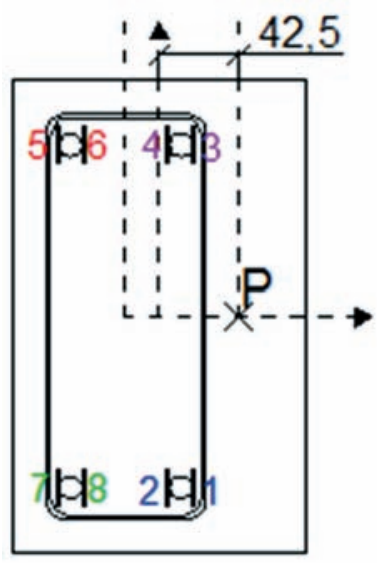

A

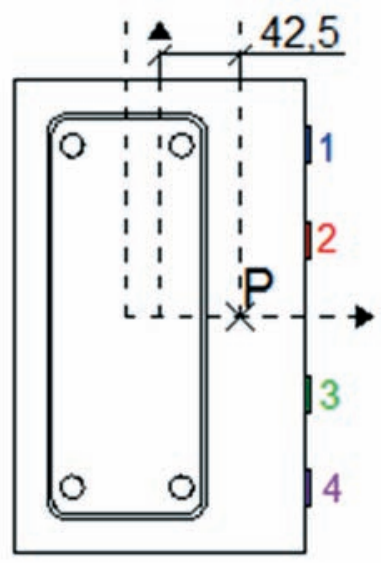

B bered 1 and 2 were positioned at the compressive face and rebars 3 and 4 were positioned at the tension face. Eight electrical strain gauges were attached to rebars at column mid-height to monitor longitudinal reinforcement strain as shown in Figure 6. Previously, mechanical properties of the steel were determined by direct tension test. These tests indicate a yield strain $\varepsilon_{\mathrm{y}}$ of $2,78 \mathrm{~mm} / \mathrm{m}$. Concrete strains were measured also at column mid-height by four concrete strain gauges placed on the most compressed face as shown in Figure 6.

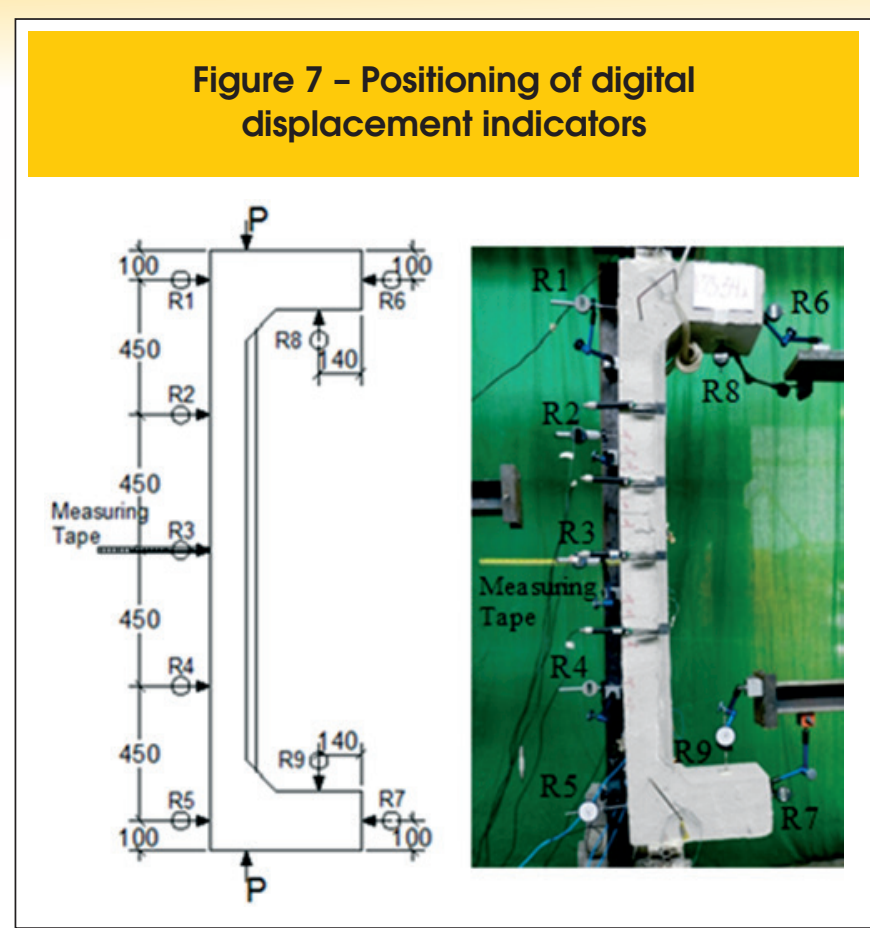

Horizontal and vertical displacements were measured by digital displacement indicators as shown in Figure 7. Indicators had a $0,01 \mathrm{~mm}$ precision and a $50 \mathrm{~mm}$ gauge length. Indicator installation procedure consisted on mounting a fixed device on a vertical support placed behind the column (see figure 7) and the indicator cursor was placed on small metal plates glued to the column's surface. Indicators were removed prior to rupture to avoid equipment

Figure 8 - Testing setup

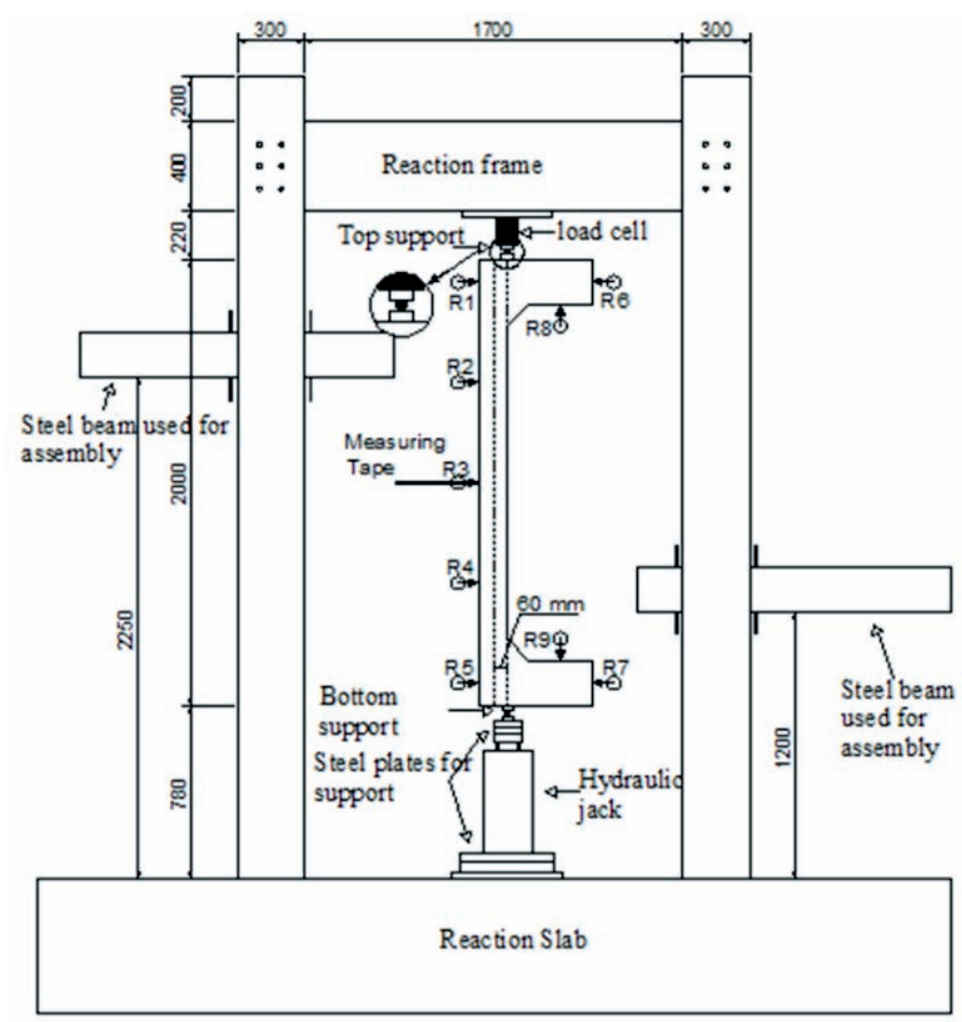




\section{Figure 9 - Cracking patterns in column P75-50}

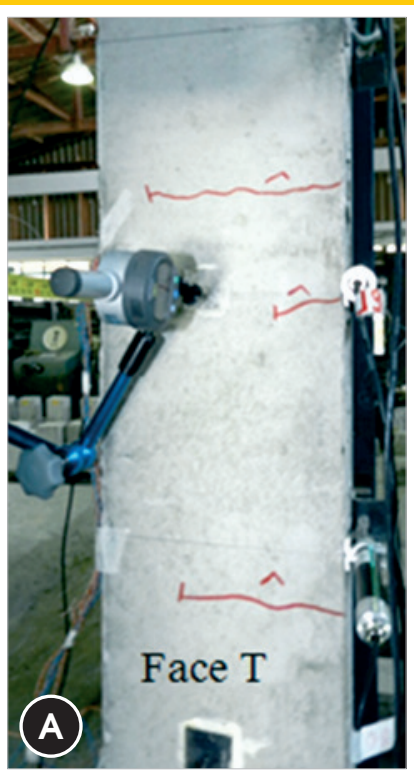

First cracks

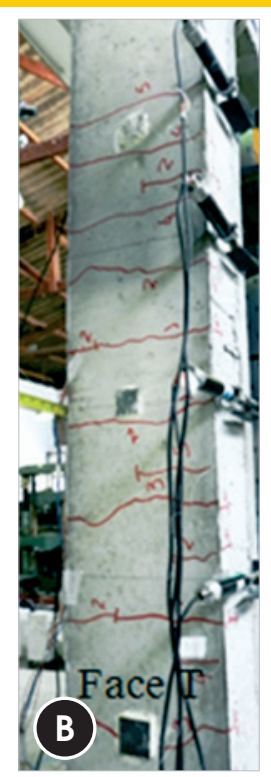

Cracking pattern near failure

damage. A complementary reading of mid-height displacement (same height as digital indicator R3 was placed) was taken using a standard measuring tape and it was used to measure horizontal mid-height displacements after removal of the digital indicators.

\subsection{Column testing}

Figure 8 presents the test setup which is basically the column

attached to a steel frame on a reaction slab. Vertical load application was done using a hydraulic jack with a 1500 kN capacity attached to a manual hydraulic pump. The hydraulic jack was placed under the column on the reaction slab. For better load measurement, two $1500 \mathrm{kN}$ capacity load cells were placed at the column's top and bottom. The load cells were attached to individual load digital indicators.

Cracking was observed and cracking patterns were registered throughout the test. Figure 9 shows cracking patters marked with a black magic marker for column P75-50. Initial cracking was observed at the $200 \mathrm{kN}$ load stage.

\section{Results and discussion}

\subsection{Ultimate loads}

Table 2 shows ultimate loads and concrete compressive strength on testing day for the concrete substrate and the new concrete layer.

The ultimate load for the monolithic reference column (PR) was $542,2 \mathrm{kN}$ and the other columns did not reach such load capacity. This load is 3,28 times larger than the one obtained by the original column (PO). Column P150-18 obtains the closest ultimate load to the reference column PR: $84 \%$ of PR's ultimate load, and column P75-42 had the worst performance: $68 \%$ of PR's ultimate load. Still the worst performance showed a load capacity increase of $190 \%$ with respect to the original column (PO) ultimate load capacity.

Columns $\mathrm{P} 150-18$ and $\mathrm{P} 150-26$ had the same vertical bolt spacing, but column P150-26 had 8 more bolts. Unexpectedly, column P150-18's ultimate load was only $2,4 \%$ higher than column P150-26's ultimate load. Comparing columns with the same vertical bolt spacing of $75 \mathrm{~mm}$, the column with the highest amount of bolts (P75-50) had the highest ultimate load. Table 2 shows that the pillar with bolts internally (P75-34i, Pu $=421,6 \mathrm{kN}$ ) had a higher breaking load to its similar with the connectors placed further apart from each other (P75-34e, $\mathrm{Pu}$ $=401,2 \mathrm{kN}$ ).

Table 2 - Concrete compressive strength at testing day and ultimate loads

\begin{tabular}{|c|c|c|c|c|c|c|}
\hline Column & $\begin{array}{c}f_{c}^{\text {sub }} \\
(M P a) / a g e\end{array}$ & $\begin{array}{c}f_{c}{ }_{c}^{\text {ref }} \\
(M P a)\end{array}$ & $\begin{array}{l}\mathrm{F}_{\mathrm{ult}} \\
(\mathrm{kN})\end{array}$ & $F_{\text {ult }} / F_{P R}$ & $F_{\text {ult }} / F_{\mathrm{PO}}$ & Mode of failure \\
\hline $\mathrm{PO}$ & 41,9 / 90 days & - & 126,7 & 0,23 & - & $\mathrm{YS} / \mathrm{CC}$ \\
\hline PR & 41,3 / 80 days & - & 542,2 & - & 4,30 & $\mathrm{CC}$ \\
\hline P150-18 & 41,4 / 83 days & 39,7 / 31 days & 453,2 & 0,84 & 3,58 & DC \\
\hline P150-26 & 41,5 / 95 days & 40, 1 / 33days & 442,5 & 0,82 & 3,49 & DC \\
\hline P75-50 & 42,2/95 days & 42,4 / 46days & 422,1 & 0,78 & 3,33 & DC \\
\hline P75-34e & $42,6 / 102$ days & 43,4 / 53days & 401,2 & 0,74 & 3,17 & DC \\
\hline P75-34i & $42,5 / 100$ days & 43,1 / 51 days & 421,6 & 0,78 & 3,33 & DC \\
\hline P75-42 & $42,7 / 105$ days & 43,7 / 55days & 367,8 & 0,68 & 2,90 & DC \\
\hline
\end{tabular}




\section{Figure 10 - Horizontal displacement on face T along column height at $300 \mathrm{kN}$ load}

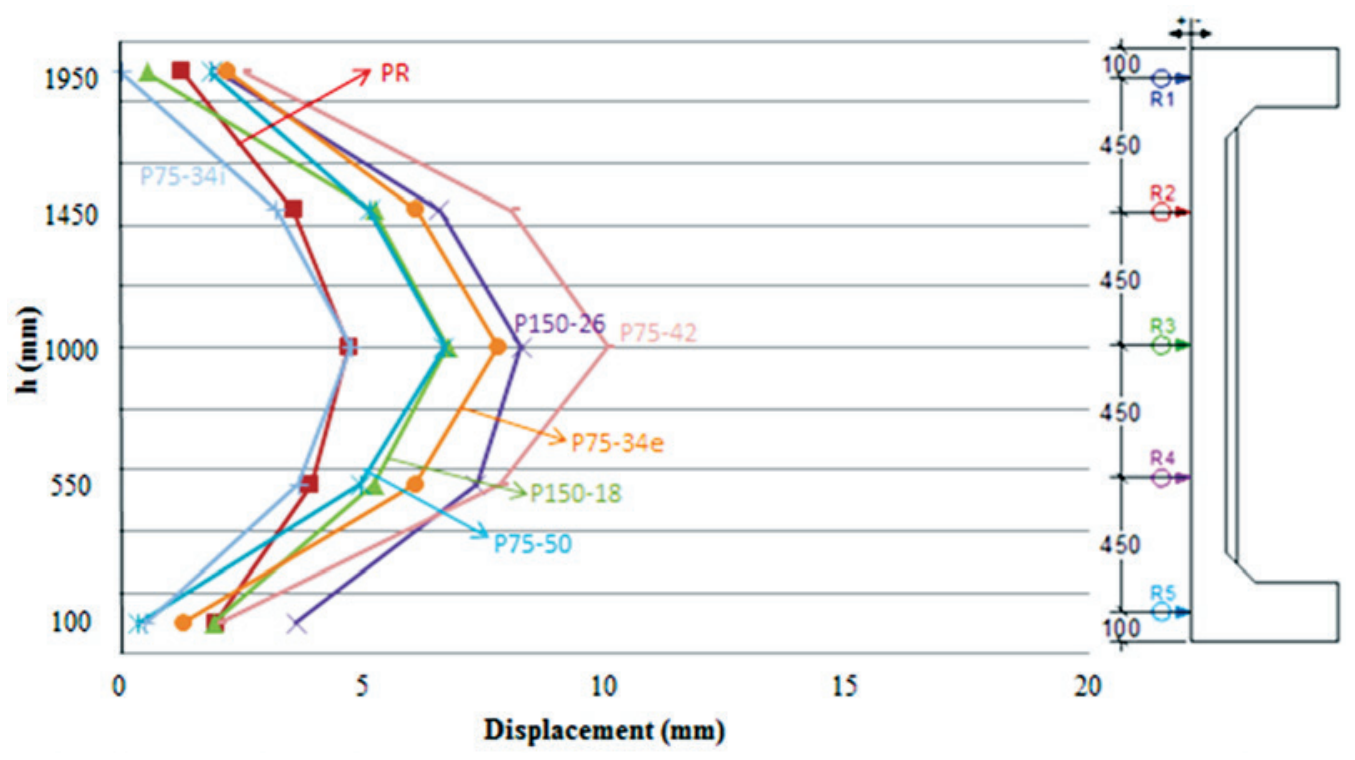

\subsection{Horizontal column displacement}

Figure 10 show typical column displacements along column height and digital indicator readings are not the same for symmetrical indicator positioning (indicators R2-R4 and R1-R5). This is due to the test setup that contributes to a non-symmetry situation. The setup is statically symmetrical, but kinetically it is not since the vertical load application is at the bottom of the column, and hence, the reaction is at the top or the superior end of the column. The bottom of the column moves as load is applied, but the top does not move. Figure 10 shows column displacements for each digital indicator placed on the tension face, namely indicators R1 to R5, at the 300

Figure 11 - Load - horizontal displacement curves for indicator R3
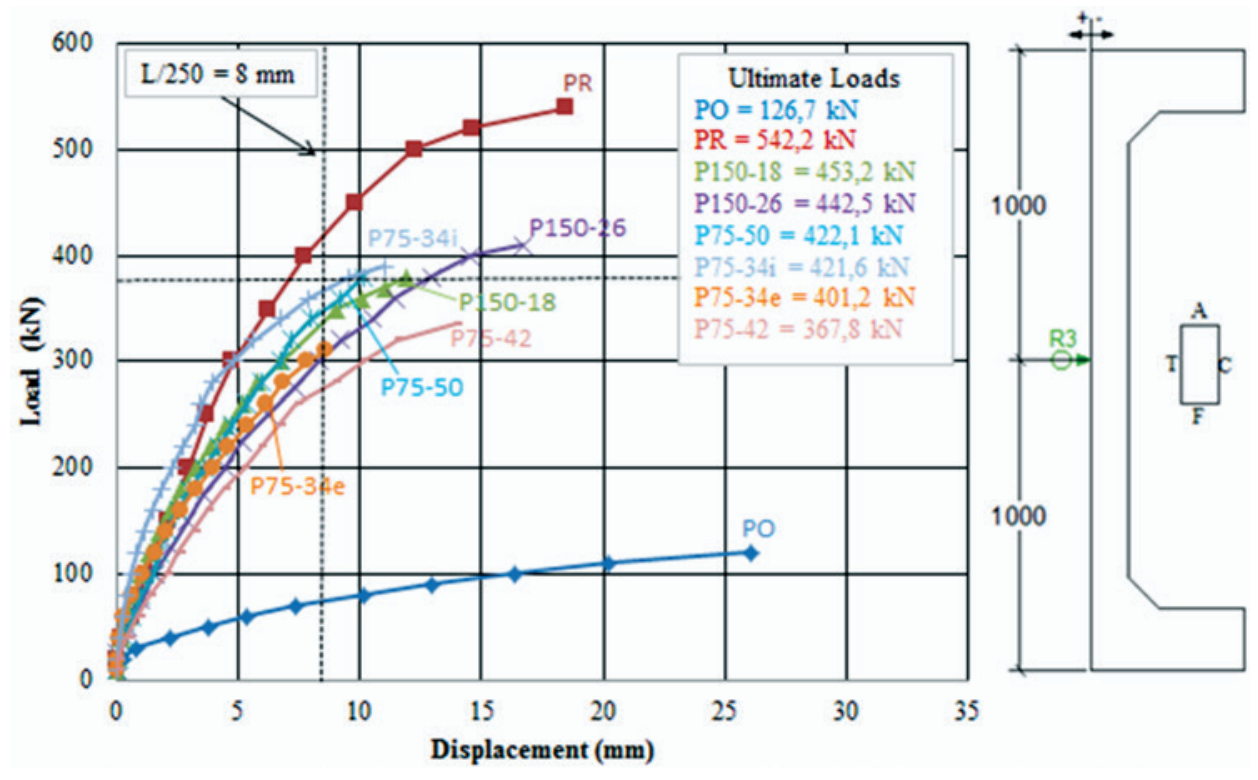
Figure 12 - Load-strain curves for longitudinal steel rebars located on the column's tension face

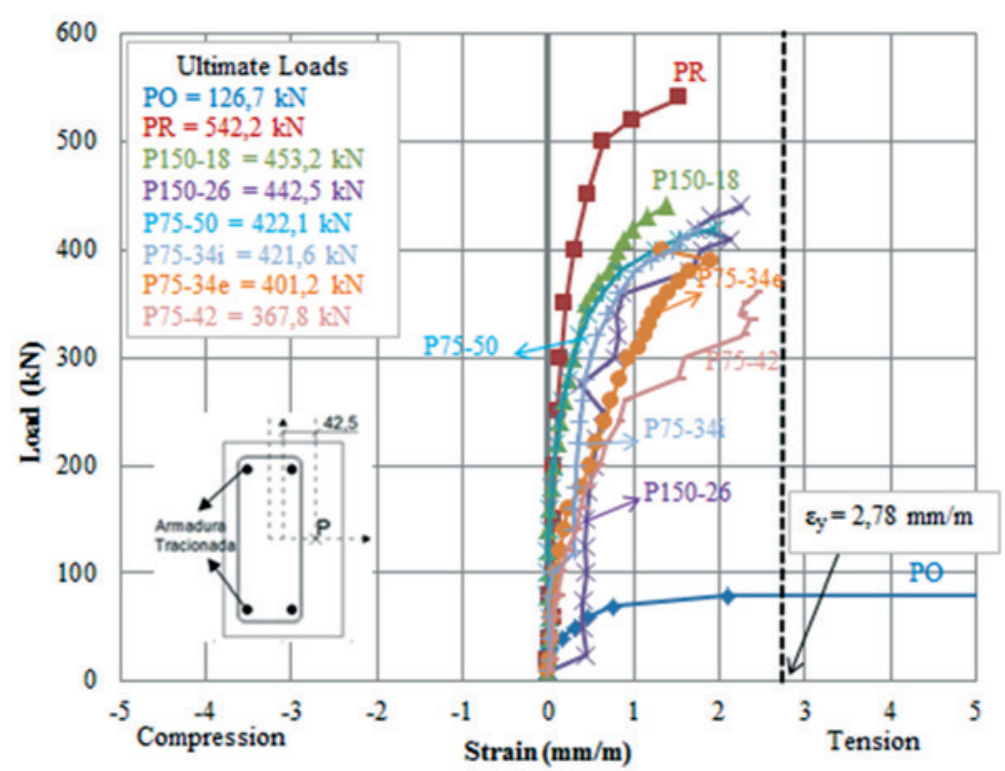

$\mathrm{kN}$ loading stage. The maximum horizontal displacements were at column mid-height (indicator R3) as expected. The figure shows that the strengthened columns showed greater horizontal displacements when compared to the ones obtained by the reference column PR at the $300 \mathrm{kN}$ loading stage, except for column P75-34i that had similar displacements to the reference column. The ulti- mate column load for the original column PO was $126,7 \mathrm{kN}$, which is lower than the $300 \mathrm{kN}$ load and, hence, column PO's displacements are not shown in this figure.

Column displacements at mid-height (indicator R3 readings) for all columns are shown in Figure 11 for all loading stages until rupture. All strengthened columns had less stiffness than column

Figure 13 - Load-concrete strain curves for all columns

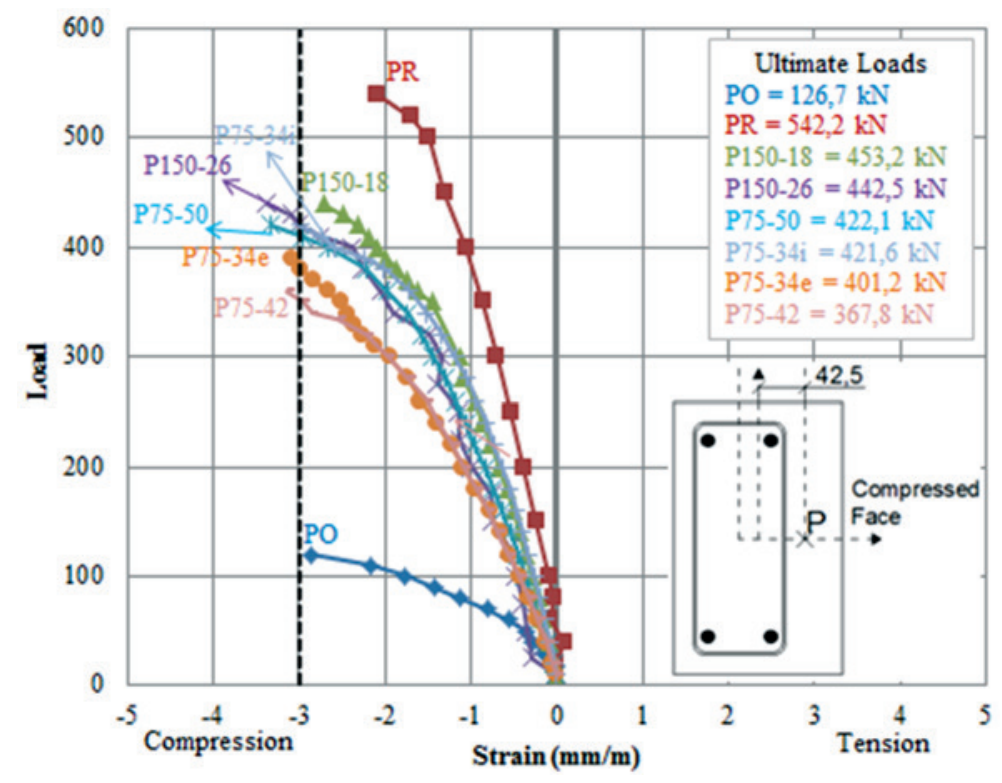


PR's stiffness, indicating the strengthened columns had a larger displacement at the same loading stage. This should be considered when designing a strengthened column using with this repairing technique.

Although Brazilian code NBR 6118:2007 [8] does not specify a limit value for column displacement at service loads, in this study, a limit of L/250 was adopted based on the code's limit for visual acceptance in beams. Since column height $L$ was equal to 2000 $\mathrm{mm}$, the displacement limit would be $8 \mathrm{~mm}$. This limit should not be surpassed at service loading. To estimate the service load, column PR's ultimate load was divided by 1,4 , which approximately corresponds to a load safety factor adopted in structural design. Thus, the service load for column PR would be $387,3 \mathrm{kN}$, and the displacement at this load is equal to $7,3 \mathrm{~mm}$, which is less than the $8 \mathrm{~mm}$ limit.

\subsection{Tension reinforcement}

To analyze longitudinal steel deformations, as those shown in Figure 12, strain gauge readings with highest strains were used. Column PO was still the only one that yielded, surpassing the yield strain of $2,78 \mathrm{~mm} / \mathrm{m}$. Tension reinforcement in column PO reached yielding at a load of $90 \mathrm{kN}$, approximately $71 \%$ of ultimate load. Maximum steel strains in other columns were between $1,35 \mathrm{~mm} / \mathrm{m}$ for column P75-34e and 2,25mm/m for column P150-26 and yielding did not occur.

\section{Figure 14 - Photographs of concrete crushing in strengthened columns}
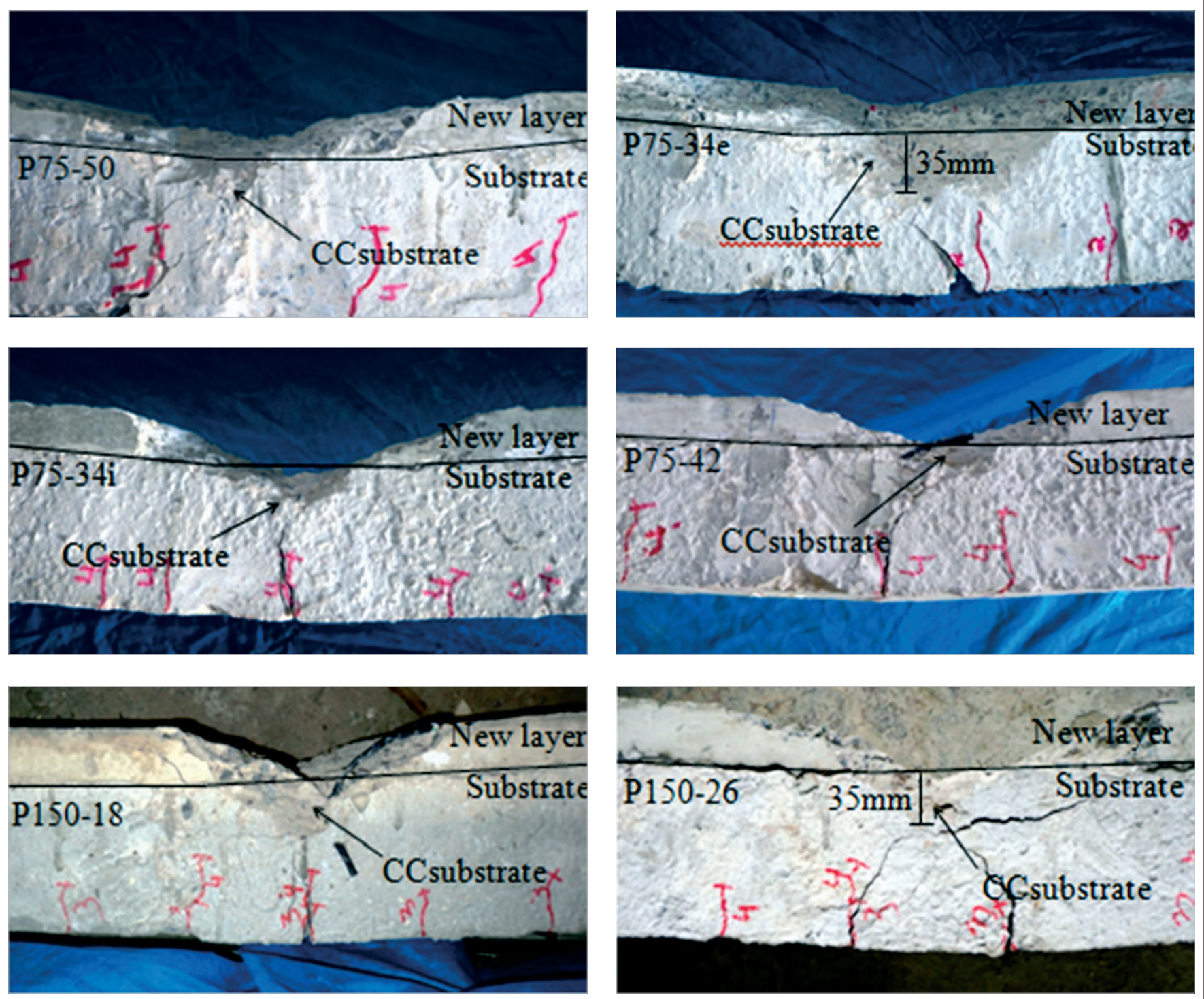

Ccsubstrate: Substrate Concrete Crushing 


\section{Figure 15 - Photograph of original column at failure}

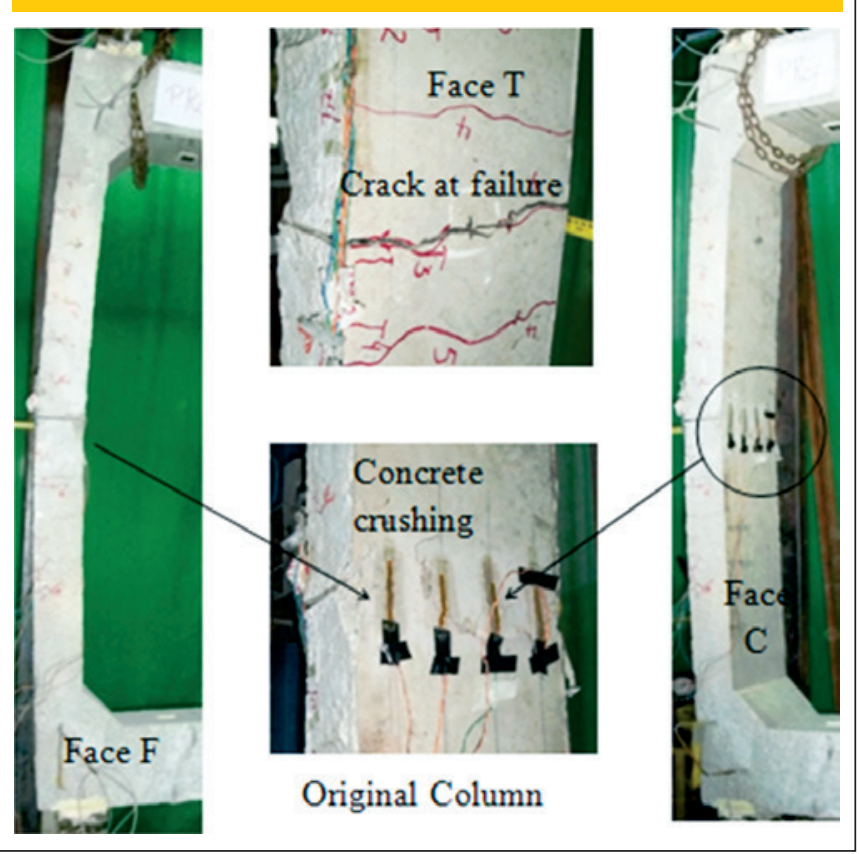

\subsection{Concrete strains}

Figure 13 shows load versus concrete strain curves. Brazilian Code NBR6118 [8] specifies an ultimate concrete strain of $3,5 \mathrm{~mm} / \mathrm{m}$ for flexure and a an ultimate strain of $2,0 \mathrm{~mm} / \mathrm{m}$ for pure compression. Since the columns were in compression and one-axis bending, the $\mathrm{ACl}$ Code $318 \mathrm{M}-02$ [10] value of $3,0 \mathrm{~mm} / \mathrm{m}$ was chosen for the ultimate concrete strain and this value is between the two values specified by the Brazilian code. Figure 14 shows that the highest concrete strains on the column face with most compression were close to the ultimate strain value for all columns.

Strengthened column P150-18, with the smallest number of bolts, had the smallest ultimate concrete strain and the highest strains occurred in columns P75-50 e P150-26. Reference column PR had an ultimate concrete strain of $2,09 \mathrm{~mm} / \mathrm{m}$.

Column $\mathrm{PO}$, with a smaller cross section, had the highest concrete strains at a given load level. At rupture, concrete strain reached a value of $2,86 \mathrm{~mm} / \mathrm{m}$, close to code value of $3,0 \mathrm{~mm} / \mathrm{m}$, and concrete crushing could be observed during the test, as shown in Figure 15.

\subsection{Modes of failure}

Failure modes for all columns are listed in Table 2 and Figures 14, 15 and 16 show photographs of the cross section of some columns at rupture.

Original column PO failed by yielding of the longitudinal tension steel reinforcement followed by crushing of the compressed concrete. Reference column PR failed by concrete crushing, but the tension steel did not yield. This was confirmed by strain gauge readings in the concrete and steel.
All strengthened columns showed detachment of the new concrete layer at rupture followed by concrete crushing of the substrate as illustrated in Figure 14. After detachment of the concrete layer, crushing of concrete substrate reached its greatest depth in columns P75-34e e P150-26 and a depth of $35 \mathrm{~mm}$ was measured from the interface. The other strengthened columns had smaller crushing depths.

Figures 15 and 16 show cracking patterns for columns PO and P75-50 at rupture and similar patterns were observed in the other columns. Concrete crushing on the most compressed column face and crack opening on the tension side (Face T) was observed in the original column PO. Detachment of the new concrete layer and crack opening on Face $T$ (tension side) was observed in column P75-50 as well as in all other strengthened columns.

\section{Conclusions}

- Although without statistical significance due to the small number of specimens, results indicate the amount and position of the bolts can influence the resistance of the strengthened columns. Unexpectedly, the column with the smallest number of bolts (column P150-18) had the highest ultimate load. Analyzing the two columns with the same number of bolts (columns P75-34i and P75-34e), positioning the bolts internally was more effective than externally. This suggests that bolt efficiency can be related to its position in the concrete layer.

- Shear failure in the bolts did not occur. Bolts presented good behavior in all cases.

- Yielding occurred only in the longitudinal reinforcement of the original column PO. Applied load eccentricity was reduced due to a cross section increase as a new concrete layer was added in the strengthened columns, causing smaller stresses due to bending moment, so yielding of the longitudinal reinforcement on the tension face did not occur.

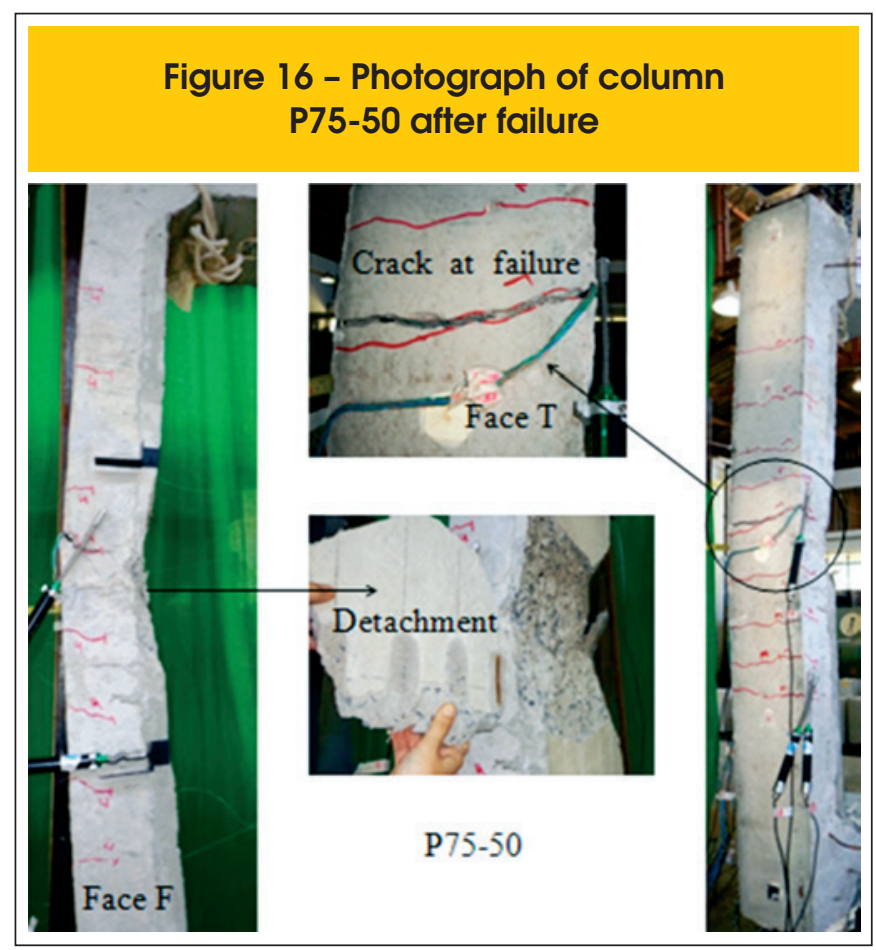


All strengthened columns had a premature failure due to the detachment of the new concrete layer from the concrete substrate. Crushing of the concrete substrate, as shown in Figure 14, occurred after detachment, once the new concrete layer no longer contributed to the column's resistance and all load was transferred to the concrete substrate. Concrete crushing occurred at rupture in the reference column and in the original column.

\section{Acknowledgements}

The authors wish to thank CAPES - Coordenação de Aperfeiçoamento de Pessoal de Nível Superior, and CNPq - Conselho Nacional de Desenvolvimento Científico e Tecnológico for the financial support,. In addition, special thanks to REALMIX for providing the self-compacting concrete and to Carlos Campos for providing the equipment necessary for preparation of the concrete substrate.

\section{References}

[01] SOUZA, R.H.F. (1990). Análise do Comportamento de vigas de betão armado reforçadas à flexão e ao esforço transverso. Lisboa, Tese (Doutorado) - Universidade Técnica de Lisboa.

[02] MORENO Jr., R. "Estudo de fatores que afetam a aderência da argamassa de reparo para estruturas de concreto". Dissertação (Mestrado) - Escola Politécnica, Universidade de São Paulo. São Paulo, 2002, 202p.

[03] OMAR, M. Y. M. Análise Experimental de Pilares de Concreto Armado Reforçados com Concreto Auto-adensável (CAA) - Volume 3, p.271, Revista Ibracon de Estruturas e Materiais, 2010.

[04] SAHB, K. F. P. Análise experimental de pilares de concreto armado submetidos à flexo-compressão, reforçados com concreto auto-adensável e chumbadores. 2008. 226p. Dissertação (Mestrado) - Universidade Federal de Goiás, Goiás, 2008.

[05] NASCIMENTO, P. P. M. Análise Experimental de Pilares de Concreto Armado Reforçados com Concreto Auto-Adensável e Conectores - Volume 5, p.305-315, Revista Ibracon de Estruturas e Materiais, 2012.

[06] MARQUES, M. G. (2013). Análise do comportamento de pilares de concreto armado reforçados com chumbadores e concreto auto adensável - Titulo provisório. Dissertação (Mestrado em andamento) - Escola de Engenharia Civil, Universidade Federal de Goiás. Goiânia.

[07] FERREIRA, D. B, Análise Experimental de Pilares de Concreto Armado, Reforçados com Concreto Autoadensável. Revista Eletrônica de Engenharia Civil - Escola de Engenharia Civil, Universidade Federal de Goiás. Goiânia, 2013.

[08] ABNT NBR 6118: Projeto de Estruturas de Concreto - Procedimento. Rio de Janeiro, 2003.

[09] EUROCODE 2: Design of Concrete Structures - General Rules and Rules for Buildings.

[10] Technical Committee - ENV 2001-1-3. Brussels, 2007.

[11] ACI COMMITTEE 318. Building Code Requirements for Reinforced Concrete and Commentary - ACl 318/08. Detroit, American Concrete Institute, 2008. 